\title{
Peningkatan Produksi dan Pendapatan Usaha Kelompok Pembesaran Nila (Oreochromis niloticus) Melalui Kegiatan Penyuluhan di Kecamatan Manisrenggo, Kabupaten Klaten
}

\author{
[Increase Production and Business Income of Tilapia Aquaculture Groups \\ (Oreochromis niloticus) Through Extension Activities in Manisrenggo \\ Subdistrict, Klaten, Central Java]
}

\author{
Restiana Budi, Ajib Kumala Sari, Octasari Wijayanti
}

Balai Pelatihan dan Penyuluhan Perikanan Tegal

\begin{abstract}
Abstrak
Budidaya nila memiliki prospek yang baik bila dikembangkan di Kabupaten Klaten. Budidaya nila dengan teknologi biofloc dipercaya memiliki beberapa kelebihan. Penelitian ini bertujuan untuk meningkatkan pengetahuan, sikap dan keterampilan kelompok pembudidaya ikan Nila Ngremboko dengan usaha pembesaran ikan nila biofloc. Selain itu, juga bertujuan untuk meningkatkan produksi dan pendapatan usaha pada kelompok pembudidaya ikan Nila Ngremboko dengan usaha pembesaran ikan nila biofloc. Metode yang digunakan dalam penelitian ini menggunakan rancangan survei yang bersifat penjelasan (explanatory research) dengan pendekatan kuantitatif dan kualitatif sebagai dasar analisis. Data yang terkumpul kemudian dianalisis dengan menggunakan analisis deskriptif. Hasil penelitian menunjukkan bahwa dengan jumlah tebar dan ukuran benih yang sama, budidaya ikan nila dengan sistem biofloc mampu menghemat pakan sebanyak $210 \mathrm{~kg}$ dibandingkan budidaya ikan nila secara konvensional, selain itu waktu pemeliharaan lebih singkat 45 hari dan menghasilkan produktivitas hasil panen $20 \mathrm{~kg}$ lebih banyak. FCR budidaya nila biofloc kurang dari 1 dengan SR 87\%. Budidaya nila dengan sistem biofloc menghasilkan keuntungan lebih besar dibandingkan budidaya nila dengan sistem konvensional. Adopsi inovasi teknologi biofloc pada budidaya nila mampu meningkatkan pengetahuan sasaran penyuluhan sebesar $34,78 \%$, meningkatkan sikap sebesar $31,64 \%$ dan meningkatkan keterampilan pembudidaya ikan sebesar $14 \%$. Terdapat 1 orang sasaran penyuluhan yang telah mencapai tahap mencoba dan 1 orang sasaran penyuluhan dalam tahap menerapkan budidaya nila dengan teknologi biofloc.
\end{abstract}

Kata kunci : biofloc; budidaya; nila; penyuluhan

\section{Abstract}

Tilapia aquaculture had good prospect to be development in Distric of Klaten, Central Java. Tilapia aquaculture with biofloc technology applied believed had several advantages. The aim oh this research was to improve konowledge, attitude and skill of Fish Farmers Group "Nila Ngremboko" by tilapia aquaculture using biofloc technology. Beside that, the goal was to improve production and income of fish farmers group "Nila Ngremboko" by tilapia aquaculture using biofloc technology. The method of this research using explanatory survey with quantitative and qualitative approached as basic of analytical. The results showed that the similar amount of fingerlings spread and fingerlings size, tilapia aquaculture using biofloc technology can save fish feed until $210 \mathrm{kgs}$ than tilapia culture in convensional way, also can reduce culture period 45 days faster than convensional way and produce $20 \mathrm{kgs}$ more than old way. Beside that, tilapia aquaculture using biofloc technology is more profitable than tilapia aquaculture in conventional way. FCR of tilapia culture less than 1 and SR ratio $87 \%$. Adoption of biofloc technology innovation on tilapia culture can improve fish farmers knowledge $34,78 \%$, improve fish farmers attitude $31,64 \%$ and improve fish farmers skill $14 \%$. There is one farmer as object of extension who reach "trial" stage and one farmer who reach "apply" stage on tilapia aquaculture using biofloc technology. 


\section{Penulis Korespondensi}

Restiana Budi | restiana.budi@gmail.com

\section{PENDAHULUAN}

Ikan Nila (Oreochromis niloticus) merupakan salah satu komoditas penting perikanan budidaya dan sangat populer di kalangan masyarakat. Hal ini karena ikan nila memiliki beberapa keunggulan dibandingkan jenis ikan air tawar lainnya. Beberapa keunggulan yang dimiliki ikan nila di antaranya adalah :relatif tingginya resistensi terhadap kualitas air dan penyakit, memiliki toleransi yang luas terhadap kondisi lingkungan, kemampuan yang efisien dalam membentuk protein kualitas tinggi dari bahan organik, limbah domestik dan pertanian, memiliki kemampuan tumbuh yang baik, dan mudah tumbuh dalam berbagai wadah budidaya yang dikelola secara tradisional maupun sistem budidaya intensif (Rochdianto 2019).

Kecamatan Manisrenggo merupakan salah satu Kecamatan di Kabupaten Klaten, Provinsi Jawa Tengah. Letak geografis Kecamatan Manisrenggo berada pada $110^{\circ} 29^{\prime} 25^{\prime \prime}$ - $110^{\circ} 29^{\prime} 56^{\prime \prime}$ BT dan 7041'46" - 742'23" LS dan mempunyai iklim tropis, dengan musim hujan dan musim kemarau silih berganti sepanjang tahun dengan temperatur udara rata-rata $23-33^{\circ} \mathrm{C}$, dengan kelembaban $80 \%$. Berdasarkan jenis pengairannya kondisi lahan sawah yang ada di Kecamatan Manisrenggo dapat digambarkan dalam 4 jenis :

a. Sawah dengan pengairan irigasi teknis seluas $158.40 \mathrm{Ha}$

b. Sawah dengan pengairan irigasi $1 / 2$ teknis dengan luas $651.60 \mathrm{Ha}$

c. Sawah dengan pengairan irigasi sederhana seluas $568.80 \mathrm{Ha}$

d. Sawah tadah hujan seluas $139 \mathrm{Ha}$

Topografi Kecamatan Manisrenggo adalah datar sampai dengan bergelombang dengan ketinggian rata-rata 250 - $375 \mathrm{~m}$ dari permukaan laut. Kecamatan Manisrenggo termasuk kategori wilayah II yang merupakan lereng Gunung Merapi. Jenis tanah di Kecamatan Manisrenggo adalah Regosol kelabu dengan $\mathrm{pH}$ tanah berkisar antara 5-7.

Dengan kondisi tersebut, maka wilayah Kecamatan Manisrenggo cocok untuk usaha Perikanan, kehutanan dan perikanan. Kecamatan Manisrenggo terdiri dari 16 Desa dengan jumlah kelompok tani sebanyak 48 kelompok dan 16 gapoktan didukung dan 15 Kelompok Pembudidaya Ikan (POKDAKAN) dengan jumlah penduduk 42.642 Jiwa dengan jumlah rumah tangga 
13.053 KK ini menggambarkan bahwa Kecamatan Manisrenggo mempunyai sumber daya yaitu tenaga kerja yang cukup potensial

Aspek kualitas SDM menjadi salah satu faktor yang mempunyai peranan besar dalam upaya membantu pencapaian keberhasilan pembangunan perikanan. Dalam hal ini kaitan perilaku sangat penting karena upaya perubahan metode serta aplikasi anjuran teknologi kerap kali menghadapi kendala karena faktor kurangnya pemahaman pembudidaya ikan terhadap tujuan, manfaat, dan dampak dari penerapan anjuran teknologi yang direkomendasikan.

Beberapa hal yang berkaitan dengan faktor lemahnya kualitas SDM sejauh ini antara lain:

a. Kurangnya basis informasi yang dimiliki pelaku utama sehingga memberikan pengaruh terhadap kemampuan untu mengambil keputusan yang berkenaan dengan pengelolaan usaha perikanan secara mandiri sulit untuk dilaksanakan.

b. Salah satu sumber pengetahuan dalam aplikasi dan pelaksanaan usaha perikanan sejauh ini hanya berdasarkan pengalaman. Lemahnya dukungan ketrampilan dan keahlian usaha perikanan yang lebih adaptif terhadap adopsi teknologi.

c. Lemahnya kemampuan inovatif, dan kreativitas dalam melakukan dan pemberdayaan pengelolaan usaha perikanan yang dilaksanakan.

Kecamatan Manisrenggo memiliki potensi yang cukup besar untuk pengembangan usaha budidaya perikanan. Selain memiliki potensi lahan yang cukup baik, juga didukung oleh potensi sumber daya manusia merupakan modal dasar dalam mengembangkan dan meningkatkan budidaya perikanan. Usaha budidaya tersebut cukup berarti dalam menopang ekonomi keluarga pembudidaya.

Usaha budidaya ikan nila sudah cukup lama dilakukan oleh kelompok pembudidaya ikan Nila Ngremboko di Desa Solodiran, Kecamatan Manisrenggo, Kabupaten Klaten. Akan tetapi, kelompok pembudidaya ikan tersebut pada umumnya masih melakukan budidaya ikan nila secara tradisional dengan produktivitas cukup rendah. Mahalnya harga pakan juga merupakan salah satu faktor yang sangat mempengaruhi keberlangsungan usaha budidaya. Upaya untuk mengatasi masalah tersebut serta untuk meningkatkan produksi perikanan, khususnya produksi ikan nila di Kecamatan Manisrenggo yang semula $98.100 \mathrm{~kg} / \mathrm{tahun}$ mampu meningkat hingga kurang lebih $10 \%$, maka perlu diupayakan suatu teknologi budidaya yang memungkinkan ikan dapat dipelihara dengan kepadatan tinggi dan kualitas media yang terkontrol. 
Teknologi biofloc menjadi salah satu alternatif pemecah masalah. Biofloc merupakan kumpulan berbagai jenis mikroorganisme (bakteri pembentuk floc, bakteri filamen, fungi), partikel-partikel tersuspensi, berbagai koloid dan polimer organik, berbagai kation dan sel-sel mati. Pada biofloc bakteri memiliki peran yang sangat dominan sebagai organisme heterotrof dan menghasilkan polyhydroxy alkanoat sebagai pembentuk ikatan biofloc. Pembentukan biofloc oleh bakteri terutama bakteri heterotrof secara umum bertujuan untuk meningkatkan pemanfaatan nutrien, menghindari stres lingkungan dan predasi (De Schryver et al. 2008). Teknologi ini yang paling menguntungkan karena selain dengan sistem padat tebar yang tinggi, juga dapat menurunkan limbah nitrogen anorganik dari sisa pakan dan kotoran di dalam kolam. Menurut (Dwimurti 2013), teknologi biofloc adalah teknologi yang memanfaatkan hasil metabolisme ikan atau udang yang mengandung nitrogen untuk diubah menjadi protein yang dapat dimanfaatkan oleh ikan atau udang, sehingga ikan atau udang tersebut memperoleh protein tambahan dari biofloc di samping pakan yang diberikan. Akumulasi dari limbah nitrogen $\left(\mathrm{NH}_{4}\right.$, $\mathrm{NO}_{2}$ ) akan dicegah oleh biofloc dengan cara menjaga $\mathrm{C} / \mathrm{N}$ Rasio tetap tinggi dan mendorong penyerapan amonium oleh mikroba. Hasil dari proses tersebut maka akan membentuk suatu komunitas mikro (bakteri,protozoa, detritus (dead body cell), jamur dan zooplankton) juga partikel serat organik yang kaya akan selulosa, partikel anorganik berupa kristal garam kalsium karbonathidrat, biopolymer dan PHA (Polyhydroxy acid). Teknologi ini juga dapat menyediakan pakan tambahan berprotein untuk ikan sehingga dapat meningkatkan pertumbuhan dan efisiensi pakan. Peran penyuluh juga sangat diperlukan, yaitu melalui pendampingan teknis dan learning by doing (belajar sambil bekerja) baik dalam penerapan dan pengembangan IPTEK maupun dalam manajemen usaha. Melalui penelitian juga akan melihat sejauh mana dampak kegiatan penyuluhan mengenai adopsi teknologi budidaya nila menggunakan teknologi biofloc pada Pokdakan Nila Ngremboko.

Tujuan dilaksanakan penelitian ini adalah :

1. Meningkatkan pengetahuan, sikap dan keterampilan kelompok pembudidaya ikan Nila Ngremboko dengan usaha pembesaran ikan nila biofloc.

2. Meningkatkan produksi dan pendapatan usaha pada kelompok pembudidaya ikan Nila Ngremboko dengan usaha pembesaran ikan nila biofloc.

\section{BAHAN DAN METODE}

Penelitian dilakukan di Kecamatan Manisrenggo, Kabupaten Klaten, Provin- 
si Jawa Tengah pada Bulan April sampai dengan Juli 2021. Penelitian menggunakan rancangan survei yang bersifat penjelasan (explanatory research) dengan pendekatan kuantitatif dan kualitatif sebagai dasar analisis. Data primer yang diperoleh dari pengamatan di lapangan, survei terstruktur dengan kuesioner dan diskusi kelompok terarah dengan responden melalui Focus Group Discussion (FGD) dan pengambilan data sekunder dari intansi terkait. Menurut Alfiyanti (2008), metode FGD ini mengandalkan perolehan data atau informasi dari suatu interaksi informan atau responden berdasarkan hasil diskusi dalam suatu kelompok yang berfokus untuk melakukan bahasan dalam menyelesaikan permasalahan tertentu. Sehingga metode ini dianggap sesuai dengan penelitian yang dimaksud. Data yang terkumpul kemudian dianalisis dengan menggunakan analisis deskriptif. Hasil dari pengolahan data tersebut dapat disajikan dalam bentuk tabel maupun dalam bentuk gambar dan grafik.

Penelitian ini difokuskan pada usaha budidaya ikan nila merah yang dilakukan dengan menggunakan dua metode yang berbeda. Metode yang pertama yaitu budidaya ikan nila merah di kolam bundar dengan memanfaatkan teknologi biofloc dan menggunakan pompa blower modifikasi, sedangkan metode yang kedua yaitu budidaya ikan nila di kolam persegi secara biasa atau konvensional. Pompa blower modifikasi memiliki fungsi yaitu untuk meningkatkan kandungan oksigen terlarut (Dissolved Oxygen) bagi ikan yang dipelihara karena pompa ini mampu menghasilkan partikel gelombang udara yang lebih kecil (microbubble). Sesuai dengan penelitian yang dilakukan oleh (Heriyati et al. 2020) mengenai uji aerasi pada budidaya nila merah, dinyatakan bahwa aerator microbubble dapat meningkatkan jumlah oksigen terlarut dalam air karena gelembung udara yang dihasilkan lebih kecil daripada ukuran gelembung yang diproduksi dari aerator biasa.

Secara umum produksi diartikan sebagai suatu kegiatan/proses yang mentransformasikan masukan (input) menjadi hasil keluaran (output). Pengertian produksi dalam arti luas sebagai kegiatan yang mentransformasikan masukan (input), tercakup semua aktivitas/ kegiatan yang menghasilkan barang/ jasa, serta kegiatan-kegiatan lain yang mendukung/menunjang usaha untuk menghasilkan produk tersebut. Sedangkan dalam arti sempit, pengertian produksi hanya di maksud sebagai kegiatan yang menghasilkan barang baik barang jadi maupun barang setengah jadi (Assauri 1999).

Pendapatan adalah selisih antara penerimaan (TR) dan total biaya (TC), jadi $\mathrm{Pd}=\mathrm{TR}-\mathrm{TC}$. Penerimaan adalah 
perkalian antara produksi yang diperoleh dengan harga jual. Biaya biasanya diklasifikasikan menjadi dua yaitu biaya tetap (Fixed Cost) dan biaya variabel (Variabel Cost). Biaya tetap adalah biaya yang relatif tetap jumlahnya dan terus dikeluarkan walaupun produksi yang diperoleh banyak atau sedikit. Biaya variabel adalah biaya yang besar kecilnya dipengaruhi oleh produksi yang diperoleh, contohnya biaya untuk tenaga kerja. Total biaya (total cost) adalah jumlah dari biaya tetap (fixed cost) dan biaya variabel (variabel cost), maka $\mathrm{TC}=$ FC + VC (Sujarno 2008).

Sasaran penyuluhan yaitu kelompok pembudidaya ikan Nila Ngremboko yang berlokasi di Desa Solodiran, Kecamatan Manisrenggo, Kabupaten Klaten. Sebagian besar anggota kelompok masih melakukan usaha budidaya ikan nila secara konvensional. Kegiatan penyuluhan perikanan dilakukan untuk meningkatkan pengetahuan, sikap dan keterampilan pelaku utama mengenai usaha perikanan yang dilakukan. Penyuluhan perikanan dalam penelitian ini untuk mengetahui sejauh mana pelaku utama memanfaatkan teknologi budidaya ikan nila. Hasil evaluasi kegiatan penyuluhan dianalisis menggunakan perhitungan (Nurjaman, Sobariah, dan Supenti 2018):

Perubahan=Post Test-Pre Test

Peningkatan $=\frac{\text { Post Test-Pre Test }}{\text { Pre Test }} \times 100 \%$
Evaluasi tingkat inovasi sasaran dikelompokkan menjadi lima tahapan, yaitu sadar, minat, menilai, mencoba dan menerapkan menggunakan pendekatan before and after comparisons. Pendekatan yang membandingkan kondisi (orang atau penduduk suatu daerah) sebelum dan sesudah program (actual post program data) terhadap grup target. Selain itu, pendekatan ini juga dapat digunakan untuk membandingkan kondisi masyarakat sesudah program dijalankan.

Secara umum finansial dari usaha perikanan diketahui dengan menganalisis Break Event Point (BEP). Analisis BEP merupakan analisis untuk mengetahui batas nilai produksi atau volume produksi suatu usaha mencapai titik impas. Fomula untuk mengetahui BEP menurut Nuraeni et al. (2005) dalam Aprilia et al. (2018):

$$
\begin{gathered}
\text { BEP (Rp) } \frac{B T}{1-\left(\frac{B T}{P J}\right)} \\
\text { BEP (Unit) }=\frac{B T}{(H J)-(B V)}
\end{gathered}
$$

Keterangan:

BT : Biaya Tetap

PJ : Penjualan

HS : Harga Jual Satuan

BV : Biaya Variabel per Satuan

Payback Period (PP) bertujuan untuk mengetahui waktu tingkat pengembalian investasi yang telah ditanamkan pada suatu usaha (Mahyuddin 2009). 


$$
\begin{gathered}
\text { Payback Period }=\frac{\text { Total Investasi }}{\text { Keuntungan }} \\
(\text { RC Ratio })=\frac{\text { Pendapatan }}{\text { Pengeluaran }}
\end{gathered}
$$

\section{HASIL DAN PEMBAHASAN}

\section{Hasil Penelitian}

Hasil penelitian ini disajikan dalam bentuk tabel dan akan dijelaskan secara rinci pada sub bab pembahasan. Tabel 1 menunjukkan perbandingan hasil panen pembesaran nila menggunakan tekno- logi biofloc dan usaha pembesaran nila secara konvensional. Tabel 2 menunjukkan perbandingan analisis usaha produksi pembesaran nila menggunakan teknologi biofloc dengan usaha pembesaran nila secara konvensional.

Kegiatan penyuluhan perikanan bertujuan untuk meningkatkan pengetahuan, sikap dan keterampilan kelompok sasaran penyuluhan beserta keluarganya. Tabel 3 memperlihatkan hasil tes

Tabel 1 Hasil panen pembesaran nila menggunakan teknologi biofloc

\begin{tabular}{clcc}
\hline No & \multicolumn{1}{c}{ Kegiatan Budidaya } & Kolam Biofloc & Kolam Non Biofloc \\
\hline 1. & Jumlah tebar (ekor) & 1500 & 1500 \\
2. & Ukuran benih (cm) & $4-6$ & $4-6$ \\
3. & Pakan (Pelet) yang diberikan (kg) & 240 & 450 \\
4. & Lama pemeliharaan (hari) & 105 & 150 \\
5. & Hasil panen (kg) & 260 & 240 \\
6. & Ukuran panen (g) & $200-250$ & $200-250$ \\
7. & FCR (Feed Conversion Ratio) & 0,92 & 1,8 \\
8. & SR (Survival Rate) (\%) & 87 & 80 \\
\hline
\end{tabular}

Tabel 2 Perbandingan analisis usaha produksi pembesaran nila dengan teknologi biofloc dengan budidaya nila konvensional

\begin{tabular}{clcc}
\hline No & \multicolumn{1}{c}{ Uraian } & Budidaya Nila Biofloc & Budidaya Nila Non Biofloc \\
\hline 1. & Investasi & 9.350 .000 & 1.850 .000 \\
2. & Biaya tetap & 300.000 & 100.000 \\
3. & Biaya variabel & 2.860 .000 & 4.605 .000 \\
4. & Pendapatan & 6.240 .000 & 5.760 .000 \\
5. & Keuntungan & 3.080 .000 & 1.055 .000 \\
6. & B/C Ratio & 2,14 & 1,9 \\
7. & BEP (Rp) & $553.505,53$ & $498.504,48$ \\
8. & PP (90 hari) & 1,28 & 1,56 \\
\hline
\end{tabular}


Tabel 3 Gambaran perubahan dan peningkatan pengetahuan hasil tes

\begin{tabular}{llccc}
\hline No & Kegiatan Test & $\begin{array}{c}\text { Nilai yang } \\
\text { Diperolah }\end{array}$ & $\begin{array}{c}\text { Perubahan } \\
\text { Pengetahuan (b-a) }\end{array}$ & $\begin{array}{c}\text { Peningkatan } \\
\text { Pengetahuan }[(\mathbf{b}- \\
\text { a)/b]x100\% }\end{array}$ \\
\hline 1. & Pre test (a) & 900 & $1.380-900=480$ & $\begin{array}{c}(480 / 1.380) \times 100 \%= \\
34,78 \%\end{array}$ \\
2. & Post test (b) & 1.380 & & \\
\hline
\end{tabular}

Tabel 4 Gambaran perubahan dan peningkatan sikap hasil tes

\begin{tabular}{llccc}
\hline No & Kegiatan Test & $\begin{array}{c}\text { Nilai yang } \\
\text { Diperolah }\end{array}$ & $\begin{array}{c}\text { Perubahan Sikap (b- } \\
\text { a) }\end{array}$ & $\begin{array}{c}\text { Peningkatan Sikap } \\
{[(\mathbf{b}-\mathbf{a}) / \mathbf{b}] \mathbf{x} 100 \%}\end{array}$ \\
\hline 1. & Pre test (a) & 460 & $673-460=213$ & $\begin{array}{c}(213 / 673) \times 100 \%= \\
31,64 \%\end{array}$ \\
2. & Post test (b) & 673 & & \\
\hline
\end{tabular}

Tabel 5 Tingkat persetujuan pre-test dan post-test keterampilan teknologi biofloc

\begin{tabular}{clcc}
\hline No & Jumlah Jawaban & Pre-Test & Post-Test \\
\hline 1. & Setuju (S) & $3 \times 5=15$ & $3 \times 7,5=22,5$ \\
2. & Kurang Setuju (KS) & $2 \times 3,1=6,2$ & $2 \times 2,5=5$ \\
3. & Tidak Setuju (TS) & $1 \times 1,9=1,9$ & $1 \times 0=0$ \\
4. & Jumlah Jawaban & 23,1 & 27,5 \\
5. & Skor Tertinggi & $10 \times 3=30$ & $10 \times 3=30$ \\
6. & Skor Terendah & $10 \times 1=10$ & $10 \times 1=10$ \\
7 & Tingkat Persetujuan & $23,1 / 30 \times 100 \%=77 \%$ & $27,5 / 30 \times 100 \%=91 \%$ \\
\hline
\end{tabular}

pelaku utama sebagai gambaran perubahan dan peningkatan pengetahuan setelah dilakukan penyuluhan mengenai usaha pembesaran nila menggunakan teknologi biofloc.

Tabel 4 menunjukkan hasil tes pelaku utama sebagai gambaran perubahan dan peningkatan sikap setelah dilakukan penyuluhan mengenai usaha pembesaran nila menggunakan teknologi biofloc. Tabel 5 menunjukkan hasil tes pelaku utama sebagai gambaran perubahan dan peningkatan keterampilan setelah dilakukan penyuluhan mengenai usaha pembesaran nila menggunakan teknologi biofloc. Tabel 6 menunjukkan tahap adopsi inovasi oleh Pokdakan Nila Ngremboko mengenai budidaya nila menggunakan teknologi biofloc.

\section{Pembahasan}

Budidaya Nila (Perbandingan Menggunakan Teknologi Biofloc dan Konvensional)

Pada penelitian ini dilakukan perbandingan antara budidaya ikan nila 
Tabel 6 Tahap adopsi inovasi budidaya nila menggunakan teknologi biofloc

\begin{tabular}{ccccccc}
\hline No & Minggu ke- & Sadar & Minat & Menilai & Mencoba & Menerapkan \\
\hline 1. & 1 & 10 & 1 & & & \\
2. & 2 & 10 & 1 & & & \\
3. & 3 & 9 & 1 & 1 & & \\
4. & 4 & 9 & 1 & 1 & & \\
5. & 5 & 8 & 2 & 1 & & \\
6. & 6 & 7 & 2 & 2 & & \\
7. & 7 & 6 & 3 & 2 & & \\
8. & 8 & 4 & 3 & 4 & & \\
9. & 9 & 3 & 4 & 3 & 1 & \\
10. & 10 & - & 5 & 4 & 1 & \\
\hline
\end{tabular}

secara konvensional (seperti yang selama ini dilakukan oleh kelompok pembudidaya ikan) dengan budidaya ikan nila menggunakan teknologi biofloc. Kedua jenis metode budidaya ikan nila menggunakan padat tebar benih dan ukuran benih yang sama. Selama ini kelompok pembudidaya ikan "Nila Ngremboko" memelihara ikan nila seperti biasa tanpa banyak perlakuan, mengandalkan pakan ikan buatan berupa pelet dan dengan aerasi seadanya. Melalui kegiatan penyuluhan berupa adopsi inovasi teknologi biofloc diharapkan mampu meningkatkan kesejahteraan pelaku utama pembudidaya ikan, khususnya Pokdakan "Nila Ngremboko".

Menurut Maulina (2009), Biofloc berasal dari dua kata yaitu Bio "kehidupan" dan floc "gumpalan". Sehingga biofloc dapat diartikan sebagai bahan organik hidup yang menyatu menjadi gumpalan-gumpalan.

Gumpalan tersebut terdiri dari berbagai mikroorganisme air termasuk bakteri, algae, fungi, protozoa, metazoa, rotifera, nematoda, gastrotricha dan organisme lain yang tersuspensi dengan detritus. Biofloc merupakan floc atau gumpalan-gumpalan kecil yang tersusun dari sekumpulan mikroorganisme hidup yang melayang-layang di air. Teknologi biofloc adalah teknologi yang memanfaatkan aktivitas mikroorganisme yang membentuk floc. Aplikasi teknologi biofloc banyak diaplikasikan di sistem pengolahan air limbah industri dan mulai diterapkan di sistem pengolahan air media akuakultur (Maulina 2009). Selanjutnya Muliadi (2020) menyatakan dalam materi paparannya, budidaya nila intensif dengan teknologi biofloc memiliki 
beberapa kelebihan, antara lain mampu menghemat penggunaan lahan (meningkatkan efektivitas dan efisiensi guna lahan), menghemat penggunaan air, menghemat pakan dan menghasilkan produktivitas tinggi. Budidaya ikan nila dengan teknologi biofloc dilaksanakan di kolam bundar milik Bapak Ardi selaku pengurus Pokdakan Nila Ngremboko. Berikut akan dijelaskan secara lebih rinci terkait penelitian yang dilakukan.

\section{Persiapan Kolam}

Hal pertama yang perlu dipersiapkan adalah kolam bundar, diameter 3 meter berbahan terpal dengan central drain dan kedalaman 1 meter. Sebelum digunakan, kolam tersebut dibersihkan dengan cara disikat hingga bersih. Setelah kolam bundar bersih kemudian diisi air bersih dan diaerasi. Tekanan aerasi yaitu 30 liter/menit/titik batu aerasi $/ \mathrm{m}^{3}$ (setara dengan $10 \mathrm{watt} / \mathrm{m}^{3}$ ). Pengelolaan aerasi ini menggunakan alat diffuser agar gelembung udara semakin banyak sehingga kandungan oksigen terlarut tercukupi. Untuk kolam bundar berdiameter 3 meter membutuhkan 6 buah diffuser dengan posisi peletakan disesuaikan sehingga oksigen bisa merata di semua kolom air kolam. Untuk kolam budidaya nila secara konvensional, tahapan budidaya dilakukan seperti pada umumnya. Seperti yang dinyatakan oleh (Salsabila dan Suprapto
2019), kegiatan pembesaran ikan nila meliputi persiapan kolam, penebaran benih, pemberian pakan, pengelolaan kualitas air, pengendalian hama dan penyakit serta pemanenan.

\section{Pembuatan Biofloc}

Bahan untuk membuat media biofloc adalah mencampurkan garam krosok $1 \mathrm{~kg} / \mathrm{m}^{3}$ dan kapur dolomit $50 \mathrm{~g} / \mathrm{m}^{3}$ dengan dilanjutkan aerasi selama kurang lebih 24 jam. Setelah itu benih ikan nila dimasukkan ke dalam kolam dengan jumlah benih 1500 ekor/kolam, ukuran 4$6 \mathrm{~cm}$. Menurut KKP (2009), penebaran benih sebaiknya dilakukan pada pagi atau sore hari pada saat temperatur udara tidak terlalu tinggi agar ikan tidak mengalami stres.

Setelah hari kelima diberikan molase atau tetes tebu sebanyak 100 $\mathrm{ml} / \mathrm{m}^{3}$ dan probiotik dengan merek dagang "aquaenzym" sebanyak 1 sachet. Berdasarkan studi literatur, probiotik aquaenzym mengandung tiga jenis bakteri, yaitu Bacillus subtilis $5 \times 10^{9}$ cfu, Bacillus meganterium $5 \times 10^{9} \mathrm{cfu}$, Bacillus polimyxa $5 \times 10^{9} \mathrm{cfu}$, selain itu juga mengandung tiga jenis enzim, yaitu enzim amilase, enzim cellulase dan enzim protease. Kualitas air diukur dan dipertahankan minimal kandungan oksigen terlarut $3 \mathrm{mg} / \mathrm{l}$ dan $\mathrm{pH}$ 6-8 serta dilakukan pengamatan warna air. Menurut Suyanto (2010), nilai pH air tempat hidup 
ikan nila berkisar antara 6-8,5. Namun, pertumbuhan optimalnya terjadi pada $\mathrm{pH}$ 7-8. Kadar oksigen terlarut 4-7 ppm. Suhu optimum $25-33^{\circ} \mathrm{C}$. Pada suhu di bawah $25^{\circ} \mathrm{C}$, ikan nila dapat hidup, tetapi pertumbuhannya lambat.

\section{Pengelolaan Biofloc}

Setelah hari kelima belas perlu dilakukan pengecekan kualitas air dan floc yang terbentuk. Dengan menggunakan alat yang sederhana, berupa potongan botol bekas air mineral dapat dilihat kandungan floc setelah diendapkan beberapa saat. Perlu dilakukan penambahan molase dan probiotik apabila kadar oksigen kurang dari 3 mg/l dan floc kurang dari $30 \mathrm{mg} / \mathrm{l}$. Namun apabila floc yang terbentuk lebih dari 50 $\mathrm{mg} / \mathrm{l}$ maka pemberian pakan buatan (pelet) perlu dihentikan karena diharapkan ikan akan memakan floc yang ada terlebih dahulu. Air media floc diusahakan berwarna kecoklatan. Air tidak perlu dilakukan penggantian selama siklus budidaya, air hanya perlu dilakukan penambahan bila terjadi penguapan.

Endapan floc yang terbentuk perlu diperhatikan secara terus menerus. Menurut hasil penelitian yang dilakukan oleh (Ombong dan Salindeho 2016), hasil pengamatan terhadap tingkat kepadatan floc menentukan tindakan apa yang harus dilakukan. Jika kepadatan terlalu tinggi, maka harus dilakukan pengenceran medium kultur. Jika kepadatan floc terlalu rendah, maka dapat ditambahkan probiotik dan molase.

Sejalan seperti yang diungkapkan oleh (Murni 2010) bahwa pemeliharaan ikan nila sangat tergantung dari kondisi lingkungan, kolam ikan seperti $\mathrm{pH}, \mathrm{CO}_{2}$, oksigen terlarut, suhu air juga aliran air yang mengalir deras dapat memberi dampak positif terhadap hasil panen karena ikan menjadi lebih cepat besar. Penelitian menggunakan teknologi biofloc dimana aerasi kolam terus berjalan selama 24 jam sehingga ikan nila yang dibudidayakan memiliki pasokan oksigen terlarut cukup dan perkembangannya optimal.

\section{Pakan}

Pakan buatan yang diberikan pada budidaya nila biofloc adalah pelet dengan kandungan protein nabati yang lebih tinggi. Selama pemeliharaan 4 hari pertama, dosis pakan yang diberikan $1 \%$ dari bobot biomassa per hari. Sampling biomassa dilakukan 10 hari sekali untuk menentukan jumlah pakan yang akan diberikan. Dosis pakan hari kelima hingga panen adalah secara satiasi (sekitar 2,5\% dari bobot biomassa per hari). Pakan diberikan sebanyak tiga kali sehari (pagi, siang dan malam hari).

Dalam budidaya ikan nila secara konvensional, persiapan kolam dilakukan dengan melakukan pembalikan tanah 
guna memperbaiki unsur hara, pemberian pupuk organik untuk menumbuhkan pakan alami, pengisian air kolam kemudian dilanjutkan dengan penebaran benih dan proses pemeliharaan. Berdasarkan hasil penelitian, dengan padat tebar dan ukuran benih yang sama, jumlah pakan yang dihabiskan dalam satu siklus pemeliharaan (dari ukuran 4$6 \mathrm{~cm}$ hingga panen) budidaya nila biofloc lebih sedikit dibandingkan budidaya nila konvensional. Selisihnya berkisar $20 \mathrm{~kg}$ per siklus, hal tersebut dapat terjadi dikarenakan pada budidaya sistem biofloc, ikan nila memperoleh asupan pakan tidak hanya dari pelet namun juga dari floc yang terbentuk. Sedangkan budidaya nila konvensional, asupan pakan hanya bersumber dari pelet yang diberikan dan sedikit ditopang dari pakan alami (fitolankton dan zooplankton) yang tersedia di kolam. Dilihat dari sudut pandang lama pemeliharaan selama satu siklus, waktu yang dibutuhkan untuk menghasilkan nila berukuran 4-5 ekor/kg dengan sistem biofloc lebih singkat 45 hari dibandingkan budidaya secara konvensional. Selain itu, tingkat konversi pakan dengan sistem biofloc lebih baik dibandingkan budidaya secara konvensional dan memiliki sintasan lebih tinggi dibandingkan budidaya secara konvensional.

Hasil perhitungan FCR (Feed Conversion Ratio) pada usaha budidaya nila menggunakan teknologi biofloc adalah 0,92 . Nilai tersebut kurang dari satu artinya dalam menghasilkan $1 \mathrm{~kg}$ daging ikan membutuhkan pakan kurang dari $1 \mathrm{~kg}$ (920 gram). Menurut (Marie et al., 2018), nilai FCR kurang dari satu akan semakin meningkatkan keuntungan usaha budidaya ikan.

\section{Panen}

Berdasarkan tabel 1 produksi hasil budidaya ikan nila menggunakan sistem biofloc menghasilkan panen lebih banyak $20 \mathrm{~kg}$ dibandingkan budidaya nila sistem konvensional dengan masa pemeliharaan yang lebih singkat 45 hari. Maka dapat dikatakan bahwa budidaya nila menggunakan teknologi biofloc memiliki produktivitas lebih tinggi dibandingkan budidaya ikan nila secara konvensional. Sejalan dengan hasil penelitian (Sukardi, Soedibya, dan Pramono 2018) bahwa teknologi biofloc dinilai menguntungkan karena selain dapat menurunkan limbah nitrogen anorganik dari sisa pakan dan kotoran, teknologi ini juga dapat menyediakan pakan tambahan berprotein untuk hewan budidaya sehingga dapat menaikkan pertumbuhan dan efisiensi pakan. Az Zahra, Supono, dan Putri (2019) juga menyatakan bahwa biofloc yang terbentuk mempunyai potensi sebagai pakan tambahan yang memiliki nutrisi protein tinggi yang dapat meningkatkan pertum- 
buhan serta meningkatkan efisiensi pakan.

Analisis Kelayakan Usaha (Biofloc dan Konvensional)

Berdasarkan data yang terdapat pada tabel 2, dapat diketahui bahwa budidaya nila dengan sistem biofloc menggunakan investasi yang lebih besar daripada budidaya dengan sistem tradisional. Hal tersebut dikarenakan budidaya nila dengan biofloc memerlukan alat pompa blower modifikasi sistem inverter $1 \mathrm{PK}$ dan diffuser untuk meningkatkan ketersediaan oksigen terlarut di kolam. Sedangkan budidaya nila tradisional tidak memerlukan hal tersebut, untuk mengisikan air kolam hanya perlu pompa air biasa. Budidaya ikan nila dengan sistem biofloc dan konvensional, keduanya layak dilakukan (menghasilkan keuntungan) karena nilai B/C Ratio keduanya lebih dari satu. Namun budidaya nila dengan sistem biofloc menghasilkan keuntungan lebih besar daripada budidaya nila konvensional, karena pakan buatan yang digunakan lebih sedikit. Berdasarkan analisis usaha yang telah dilakukan dapat diketahui bahwa terjadi peningkatan keuntungan dengan menggunakan teknologi biofloc kurang lebih sebesar $192 \%$.
Evaluasi Aspek Pengetahuan, Sikap dan Keterampilan Budidaya Nila Biofloc

Aspek Pengetahuan

Budidaya ikan nila dengan sistem biofloc berdasarkan hasil rekapitulasi kegiatan pembesaran ikan nila dengan menggunakan adopsi teknologi biofloc didapatkan perubahan dan peningkatan pengetahuan pelaku utama pokdakan Nila Ngremboko mengenai budidaya nila menggunakan teknologi biofloc sebagaimana tersaji pada tabel 3. Hasil nilai ratarata yang diperoleh pada evaluasi awal yaitu sebanyak 900 , sedangkan evaluasi akhir adalah 1.380 sehingga terjadi perubahan sebanyak 480 dan peningkatan pengetahuan sebanyak $34,78 \%$. Perubahan dan peningkatan pengetahuan disebabkan karena sasaran penyuluhan sebelumnya belum mengetahui bahwa teknologi biofloc memiliki banyak keunggulan dibandingkan budidaya ikan nila secara konvensional.

\section{Aspek Sikap}

Berdasarkan hasil rekapitulasi kegiatan penggunaan teknologi biofloc pada pembesaran ikan nila diperoleh peningkatan perubahan sikap sasaran penyuluhan sebagaimana terlihat pada tabel 4., dengan nilai sebesar 213 dan peningkatan nilai terhadap sikap pembudidaya adalah $31,64 \%$. Sikap sasaran penyuluhan dalam menerima teknologi baru di bidang budidaya nila yaitu teknologi biofloc yang semakin mening- 
kat mengindikasikan bahwa teknologi tersebut diterima dengan baik oleh sasaran penyuluhan. Evaluasi pada aspek sikap terhadap kegiatan pemanfaatan teknologi biofloc untuk pembesaran ikan nila dilakukan dengan kriteria Sangat Setuju (SS), Setuju (S), RaguRagu (RR), Tidak Setuju (TS) dan Sangat Tidak Setuju (STS). Hasil evaluasi awal terhadap kegiatan penyuluhan penggunaan teknologi biofloc adalah 460 termasuk dalam kriteria Ragu-Ragu, sedangkan pada evaluasi akhir diperoleh 673 termasuk dalam kriteria Sangat Setuju.

\section{Aspek Keterampilan}

Aspek keterampilan yang dicapai oleh sasaran penyuluhan setelah dilakukan evaluasi yaitu kemampuan anggota pokdakan Mina Ngremboko dalam mengaplikasikan teknologi biofloc budidaya nila secara langsung pada unit usaha perikanan yang dilakukan. Evaluasi keterampilan dilakukan dengan menggunakan empat indikator terampil, cukup terampil, kurang terampil dan tidak terampil, pada evaluasi awal yang dilakukan mendapatkan tingkat persetujuan $77 \%$. Setelah dilakukan evaluasi akhir aspek keterampilan mendapatkan tingkat persetujuan $91 \%$. Peningkatan nilai tersebut mengindikasikan kemampuan sasaran penyuluhan (Pokdakan Mina Ngremboko) meningkat dalam mene- rapkan keterampilan budidaya nila dengan teknologi biofloc. Pada awal dilakukan evaluasi, tingkat persetujuan oleh sasaran penyuluhan masih rendah, hal tersebut dikarenakan teknologi biofloc belum terlalu dikenal oleh pembudidaya ikan di Kecamatan Manisrenggo. Saat dilakukan penyuluhan pertama kali, mereka menganggap bahwa teknologi ini terlalu rumit untuk dilakukan dan banyak komponen tambahan. Namun seiring berjalannya waktu dan melihat prospek menguntungkan di masa mendatang maka sasaran penyuluhan mulai setuju dengan teknologi biofloc pada budidaya nila.

\section{Evaluasi Aspek Adopsi Inovasi}

Evaluasi aspek adopsi inovasi biofloc dapat dilihat pada tabel 5. Pada minggu pertama dan kedua, dari total keseluruhan anggota Pokdakan Nila Ngremboko sejumlah 11 orang, 10 orang pada tahap sadar dan 1 orang pada tahap minat. Hal tersebut dikarenakan intensitas penyuluhan mengenai budidaya nila dengan teknologi biofloc baru dua kali diberikan kepada sasaran penyuluhan. Pada minggu ketiga dan keempat, terdapat 9 orang pada tahap sadar, 1 orang pada tahap minat dan 1 orang sudah pada tahap menilai. Pada minggu kelima, pelaku utama pada tahap sadar berkurang menjadi 8 orang, sedangkan tahap minat menjadi 2 orang 
dan tahap menilai tetap 1 orang. Pada minggu keenam, 7 orang berada dalam tahap sadar, 2 orang pada tahap minat dan 2 orang pada tahap menilai. Mulai minggu ketujuh dan kedelapan, belum ada yang sampai pada tahap mencoba. Hal tersebut dikarenakan, sasaran penyuluhan masih belum yakin atau ragu-ragu akan efektifitas teknologi biofloc, masih merasa belum bisa mengaplikasikan teknologi tersebut dan kesulitan dalam penyediaan sarana prasarana teknologi biofloc, serta perasaan takut gagal. Pada minggu kesembilan, sudah terdapat 1 orang yang berada pada tahap mencoba teknologi biofloc ini, beliau merupakan seorang pembudidaya ikan milenial dengan usia yang relatif muda. Pembudidaya ini cukup berani mengambil resiko untuk mengaplikasikan teknologi baru tersebut, karena beliau yakin akan tingkat keberhasilan teknologi biofloc ini. Pada minggu terakhir penelitian, tidak ada lagi sasaran penyuluhan pada tahap sadar, 5 orang menyatakan minat akan teknologi biofloc, 4 orang pada tahap menilai untuk mengaplikasikan teknologi ini, 1 orang pada tahap mencoba dan 1 orang pada tahap menerapkan.

\section{SIMPULAN}

Hasil penelitian ini menunjukkan bahwa:
1) Hasil pembesaran ikan nila menggunakan teknologi biofloc menghasilkan dampak yang signifikan dibandingkan dengan budidaya nila sistem konvensional. Hal tersebut ditunjukkan pada jumlah pakan yang dapat dihemat sebanyak $210 \mathrm{~kg}$, lama pemeliharaan 45 hari lebih cepat dengan ukuran tebar benih ikan yang sama, hasil panen $20 \mathrm{~kg}$ lebih banyak, FCR lebih rendah dan kurang dari satu, serta menghasilkan SR 87\%.

2) Budidaya nila dengan sistem biofloc dan konvensional samasama layak dilakukan karena nila B/C Ratio keduanya lebih dari satu, namun budidaya nila dengan sistem biofloc menghasilkan keuntungan lebih besar daripada sistem konvensional.

3) Dengan demikian teknologi biofloc ini memiliki keunggulan yaitu: hemat penggunaan lahan, hemat sumber daya air, hemat penggunaan pakan dan menghasilkan produktivitas tinggi.

4) Peningkatan peran dan fungsi kelompok sebagai wadah pembelajaran, wahana kerja sama dan sebagai organisasi kegiatan bersama melalui kegiatan penyuluhan.

5) Peningkatan pengetahuan, sikap dan keterampilan sasaran penyu- 
luhan ditunjukkan dengan hasil analisis yang dilakukan.

6) Peningkatan produksi dan pendapatan usaha pelaku utama melalui budidaya nila dengan sistem biofloc.

7) Proses adopsi inovasi teknologi budidaya nila dengan sistem biofloc berhasil dilakukan.

\section{PERSANTUNAN}

Ucapan terima kasih penulis ucapkan kepada Pokdakan Nila Ngremboko sebagai lokasi penelitian, Pemerintah Kecamatan Manisrenggo, Dinas Pertanian, Ketahanan Pangan dan Perikanan Kabupaten Klaten (khususnya Bidang Perikanan), yang telah memfasilitasi informasi data penunjang, serta seluruh pihak yang tidak dapat disebutkan satupersatu.

\section{DAFTAR PUSTAKA}

Afiyanti, Yati. 2008. "Focus Group Discussion (Diskusi Kelompok Terfokus) sebagai Metode Pengumpulan Data Penelitian Kualitatif." Jurnal Keperawatan Indonesia 12(1):58-62.
Aprilia, Cindy, Nazariah, Sobariah, dan

Sudinno Dinno. 2018.

"Pendampingan Kelompok Usaha

Pembesaran Ikan Lele di

Kecamatan Teluk Sebong

Kabupaten Bintan Kepulauan

Riau." Prosiding Seminar Nasional

Perikanan dan Penyuluhan 2018 3:1005.

Assauri, Sofian. 1999. Manajemen Produksi dan Operasi. Jakarta (ID): Fakultas Ekonomi Universitas Indonesia.

Az Zahra, Sakinah, Supono, dan Berta Putri. 2019. "Pengaruh Feeding Rate (FR) yang Berbeda Terhadap Pertumbuhan dan Tingkat Kelulushidupan Benih Ikan Nila (Oreochromis Niloticus) yang Dipelihara dengan Sistem Bioflok." Jurnal Akuakultur Rawa Indonesia 7(2):86-98.

Dwimurti, Nitya. 2013. "Pengaruh Pemberian Pakan Alami Bioflok sebagai Upaya Pencegahan Infeksi Aeromonas hydrophila pada Benih Ikan Mas Koki." Universitas Padjajaran. 
Heriyati, Eny, Rustadi Rustadi, Alim Isnansetyo, dan Bambang Triyatmo. 2020. "Uji Aerasi Microbubble dalam Menentukan Kualitas Air, Nilai Nutrition Value Coefficient (NVC), Faktor Kondisi (K) dan Performa pada Budidaya Nila Merah (Oreocrhomis Sp.)." Jurnal Pertanian Terpadu 8(1):2741.

KKP. 2009. Petunjuk Teknis Budidaya Ikan Nila Gesit di Kolam. Jakarta (ID): Direktorat Produksi, Direktorat Jenderal Perikanan Budidaya.

Mahyuddin, Kholis. 2009. Panduan Lengkap Agribisnis Perikanan. Jakarta (ID): Penebar Swadaya.

Marie, Roose, Mochammad Ali Syukron, dan Seto Sugianto Prabowo Rahardjo. $2018 . \quad$ "Teknik Pembesaran Ikan Nila (Oreochromis niloticus) dengan Pemberian Pakan Limbah Roti." Jurnal Sumber Daya Alam dan Lingkungan 5(1).

Maulina. 2009. "Aplikasi Teknologi Bioflok dalam Budidaya Udang Putih (Litopenaeus vannamei Boone)." Institut Teknologi Bandung.

Muliadi, Ari. 2020. Budidaya Nila Intensif dengan Teknologi Biofloc. Medan (ID): Balai Pelatihan dan Penyuluhan Perikanan Medan.
Murni, Adria Prilianti. 2010. "Pengaruh Stimulan Pakan Ikan (SPI) untuk Pembesaran Nila Merah (Oreochromis sp) yang Dipelihara di Waring Ikan." Hal. 135-42 in Prosiding Simposium dan Pameran Teknologi Aplikasi Isotop dan Radiasi. Jakarta (ID): Badan Tenaga Nuklir Nasional.

Nurjaman, Agung, Sobariah, dan Lilis Supenti. 2018. "Pendampingan Kelompok Usaha Pengolahan Ikan Asin di Desa Pangandaran Kabupaten Pangandaran Provinsi Jawa Barat." Hal. 945 in Seminar Nasional Perikanan dan Penyuluhan 2018. Bogor: Masyarakat Iktiologi Indonesia.

Ombong, Frandy, dan Indra R. .. Salindeho. 2016. "Aplikasi Teknologi Bioflok (BFT) pada Kultur Ikan Nila (Orechromis niloticus)." e-Journal BUDIDAYA PERAIRAN 4(2):16-25.

Rochdianto, Agus. 2019. "Teknik Budidaya Ikan Nila." Diambil (diskan.tabanankab.go.id/2019/10/ 29/teknik-budidaya-ikan-nila/).

Salsabila, Meidiana, dan Hari Suprapto. 2019. "Teknik Pembesaran Ikan Nila (Oreochromis niloticus) di Instalasi Budidaya Air Tawar Pandaan, Jawa Timur." Journal of Aquaculture and Fish Health 7(3):118. 
De Schryver, P., R. Crab, T. Defoirdt, N. Boon, dan W. Verstraete. 2008. "The basics of bio-flocs technology: The added value for aquaculture." Aquaculture 277(3-4):125-37.

Sujarno. 2008. "Analisis Faktor-Faktor yang Mempengaruhi Pendapatan Nelayan di Kabupaten Langkat." USU.
Sukardi, Purnama, Petrus Hary Tjahja Soedibya Soedibya, dan Taufik Budhi Pramono. 2018. "Produksi budidaya ikan nila (Oreochromis niloticus) sistem bioflok dengan sumber karbohidrat berbeda." Jurnal AJIE - Asian Journal of Innovation and Entrepreneurship 03(02):198-203.

Suyanto, Rachmatun. 2010. Perbenihan dan Pembesaran Nila. Jakarta (ID): Penebar Swadaya. 